www.banglajol.info/index.php/JSF

J Sci Foundation, January-June 2012;10(1):20-28

ISSN 1728-7855

\title{
Influence of Date of Planting on the Growth and Yield of Locally Popular Traditional Aromatic Rice Varieties in Boro Season
}

\author{
M A Mannan', M S U Bhuiya ${ }^{2}$, M I M Akhand ${ }^{3}$ and M M Rana ${ }^{4}$
}

\begin{abstract}
The experiment was conducted at the Bangladesh Rice Research Institute Farm, Gazipur, in boro season to determine the optimum planting date and to select the varieties having high yield potential. Traditional aromatic photoperiod sensitive fine rice varieties; Kalijira, Kataribhog, Chinigura and Badshabhog were transplanted from 10 December and continued up to 25 January, both in 2000 and 2001 years, at an interval of 15 days. Forty-day old seedlings were transplanted spaced at $20 \mathrm{~cm} \times 20 \mathrm{~cm}$. Results exhibited that plant tallness, number of tillers and dry matter increased with the advancement of planting dates. On the contrary, the number of panicles, grains panicle ${ }^{-1}$, panicle length, grain yield, straw yield and growth duration decreased with delaying of planting dates. The intermediate short stature plant type of Chinigura exhibited higher number of panicles (300-331 $\mathrm{m}^{-2}$ ) and comparatively heavier individual grain (12.25-12.31 g), consequently gave higher grain yield (2.79-3.53 t $\mathrm{ha}^{-1}$ ) planted with in December. However, in late planted situation in 10 January Kalijira exhibited higher number of panicles, grains panicle ${ }^{-1}$, resulted higher grain yield than the rest of the varieties. Thus, cultivation of traditional aromatic fine rice Chinigura and Kalijira have the potentiality to produced higher grain yield when planted in early December in Boro season.
\end{abstract}

Keywords: Planting date, Traditional aromatic rice, Photoperiod sensitive, Boro season

\section{INTRODUCTION}

Rice production has been given the highest priority in the world in meeting the demands of its ever-increasing population (Bhuiyan et al., 2004). Majority of the world people choose rice as their food to meet up their daily diet (BRRI, 2001). Rice is grown under an extremely wide range of environmental conditions (Islam et al., 1999) and growth of which depends on the surrounding climatic condition (BRRI, 2001). In Bangladesh the modern varieties make up $94.7 \%$ of rice area in the boro and $39 \%$ in Aman seasons (Karim, 1997). With the increase of self sufficiency, most of the consumers prefer fine rice compared to coarse one. At present

\footnotetext{
${ }^{1}$ Agronomy Division, Bangladesh Rice Research Institute, Gazipur

${ }^{2}$ Department of Agronomy, Bangladesh Agricultural University, Mymensingh

${ }^{3}$ Agronomy Division, Bangladesh Rice Research Institute, Gazipur

${ }^{4}$ Agronomy Division, Bangladesh Rice Research Institute, Gazipur
} 
the demand of fine rice increasing in many countries but the production is not at par accordingly. Previously the traditional aromatic fine rice varieties were very popular to the consumers which were grown in Aman season. But the grain yield of rice in Aman season is lower than that in boro season due to prevailing climatic conditions among which the uninterrupted sunlight for the whole day. For this reason, farmers are willing to grow aromatic fine rice in boro season to obtain higher grain yield. Moreover, the price of fine rice is higher than that of coarse rice (Biswas et al., 1992) specially the aromatic once which are gaining popularity in Bangladesh, South-east Asia even in the Middle East (Yoshihashi, 2005).

However, the potential varieties can give satisfactory yield only when planted in appropriate time. Date of transplanting has a great influence on the growth, yield and yield contributing characters of rice even in grain quality (Islam et al., 1999). Even slight changes in transplanting time substantially changes grain yields, growth duration and grain quality due to changes of air temperature and solar radiation (BRRI, 2003). But there exists risk to cultivate the traditional photoperiod sensitive aromatic rice varieties in boro season. Because, photoperiod sensitive fine rice varieties were recommended to cultivate in Aman season to obtain better quality. The main risk to cultivate photo-period sensitive varieties in boro season is that they will not flower when seeded beyond the cutoff date in November (BRRI, 2003; BRRI, 1996; Zaman, 1981).

So, it is important to determine the optimum date of planting and to select fine rice aromatic varieties having high yield potential for growing in Boro season to obtain higher grain yield.

\section{MATERIALS AND METHODS}

The experiment was done at the Bangladesh Rice Research Institute Farm, Gazipur, during Boro season. Forty-day-old seedlings of traditional aromatic rice Kalijira, Kataribhog, Chinigura and Badshabhog were transplanted started from 10 December, 25 December, 10 January and 25 January both in 2000 and 2001 years, spaced at $20 \mathrm{~cm} \times 15 \mathrm{~cm}$ by using 2-3 seedlings hill $^{-1}$. The treatments were distributed in a split-plot design, placing planting date in the main plot and varieties in the sub plot and replicated thrice. Fertilizers were applied @ 80-60-40-10-4 kg N, $\mathrm{P}_{2} \mathrm{O}_{5}, \mathrm{~K}_{2} \mathrm{O}, \mathrm{S}$ and $\mathrm{Zn} \mathrm{ha}^{-1}$, respectively through urea, triple super phosphate, muriate of potash, gypsum and zinc sulphate during final land preparation except urea.

Urea was top-dressed in three equal splits at 15 days after transplanting (DAT), 30 DAT and at 5 days before panicle initiation as per BRRI (2004). The crop field was kept weed free by 2 hands weedings at 20 and 40 DAT of each planting date. The plant height, tiller number and dry matter were measured at different growth stages at 15 day intervals starting from 30 DAT. Five destructive sample hills were collected from each individual plot outside of the harvested area to measure different growth parameters. The plant height was measured and the tillers were counted from the sample hills.

The same sample was also used for the dry matter determination drying them in an oven for 72 hours. For grain yield five square meter areas was harvested from the center of the plot. The grain yield was adjusted to $14 \%$ moisture content and expressed in ton ha ${ }^{-1}$. The straw was dried in the sun until complete drying. Results were made on averaging the values of two years. Data were analyzed and the means were compared using computer package"Irristat" developed by IRRI (IRRI, 1992). 


\section{RESULTS AND DISCUSSION}

\section{Plant height, tiller number and dry matter}

Plant height, tiller number and dry matter of rice affected significantly by the transplanting dates. The shorter plants were found in the early-planted crop at different growth stages. The plant height gradually increased with the advancement of planting dates irrespective of planting dates (Table 1). This fact well agrees with the results obtained by Pathak et al., (2003) where they found stunted growth of Boro crop at the early stage which may be attributed to cold spell for long period at the vegetative growth stage and with the rise of air temperature the plant height gradually increased. Roy (1999) also put similar opinion. Rice transplanted in December gave lower number of tillers which increased progressively with the advancement of planting dates up to 10 January irrespective of growth stages (Table 1).

Table 1: Effect of planting date on the plant height, tiller number and dry matter of modern aromatic fine rice varieties in Boro seasons (Average of two years)

\begin{tabular}{|c|c|c|c|c|c|c|c|c|c|c|}
\hline \multirow[t]{2}{*}{$\begin{array}{l}\text { Planting } \\
\text { date }\end{array}$} & \multicolumn{4}{|c|}{ Plant height $(\mathrm{cm})$ at different DAT } & \multicolumn{3}{|c|}{$\begin{array}{l}\text { Number of tillers }\left(\mathrm{m}^{-2}\right) \text { at } \\
\text { differentDAT }\end{array}$} & \multicolumn{3}{|c|}{$\begin{array}{l}\text { Dry matter }\left(\mathrm{tha}^{-1}\right) \text { at } \\
\text { different DAT }\end{array}$} \\
\hline & 胥 & $\begin{array}{l}\text { 紊 } \\
\text { 合 }\end{array}$ & $\frac{\sqrt{4}}{8}$ & $\begin{array}{l}\text { 盆 } \\
\text { 蛋 }\end{array}$ & 点 & $\begin{array}{l}\text { 客 } \\
\text { 察 }\end{array}$ & 客 & 牮 & 客 & $\frac{\operatorname{t}}{8}$ \\
\hline 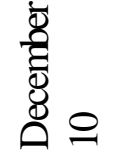 & $37.56 \mathrm{c}$ & $57.47 d$ & $69.04 d$ & $107.87 \mathrm{~b}$ & $114 \mathrm{c}$ & $260 \mathrm{c}$ & $347 \mathrm{c}$ & $0.21 d$ & 1.01d & $2.46 \mathrm{~d}$ \\
\hline 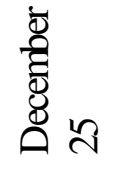 & $49.84 b$ & $60.09 \mathrm{c}$ & $76.10 \mathrm{c}$ & $10857 b$ & $168 b$ & $329 b$ & $383 b$ & $0.41 \mathrm{c}$ & $1.67 \mathrm{c}$ & $2.85 \mathrm{c}$ \\
\hline $\begin{array}{l}\text { 음 } \\
\text { 촐 } \\
\text { 茍 }\end{array}$ & $\begin{array}{c}51.16 \mathrm{a} \\
\mathrm{b}\end{array}$ & $62.29 \mathrm{~b}$ & $79.67 \mathrm{~b}$ & 10931ab & $191 \mathrm{a}$ & $339 a b$ & $391 \mathrm{ab}$ & $0.51 b$ & $1.92 \mathrm{~b}$ & $3.23 b$ \\
\hline $\begin{array}{l}\text { 年 } \\
\text { 忢 } \\
\text { 茍 }\end{array}$ & $51.67 \mathrm{a}$ & $67.24 \mathrm{a}$ & $81.17 \mathrm{a}$ & $11039 a$ & $193 \mathrm{a}$ & $350 \mathrm{a}$ & $399 a$ & $0.62 \mathrm{a}$ & $2.25 \mathrm{a}$ & $3.9 \mathrm{a}$ \\
\hline$\sum^{\text {हैँ }}$ & 47.56 & 61.77 & 76.50 & 109.04 & 1665 & 3195 & 380 & 0.44 & 1.71 & 3.11 \\
\hline$\frac{60}{52}$ & 0.01 & 0.01 & 0.01 & 0.01 & 0.01 & 0.01 & 0.01 & 0.01 & 0.01 & 0.01 \\
\hline$z e$ & 4.1 & 3.9 & 2.4 & 2.8 & 8.3 & 6.5 & 2.5 & 10.2 & 3.6 & 5.5 \\
\hline
\end{tabular}

*Figures in a column followed by different letters differ significantly, whereas, with common letter(s) do not differ significantly at $1 \%$ levels of significance. 
Among the tested varieties, the Badshabhog and Kalijira showed taller plants (Table 2) while, the Chinigura was shorter irrespective of growth stages even at the maturity stage. The Chinigura produced significantly the greatest number of tillers followed by Kalijira at early, mid and at later growth stages (Table 2). On the other hand, the lower number of tillers was observed in Badshabhog irrespective of planting dates. Similar findings were also reported by Gomosta et al (2001).

Table 2: Plant height, tille $r$ number and dry matter production of fine aromatic rice varieties in boro seasons (Average of two years)

\begin{tabular}{|c|c|c|c|c|c|c|c|c|c|c|}
\hline \multirow[t]{2}{*}{ Varieties } & \multicolumn{4}{|c|}{$\begin{array}{c}\text { Plant height (cm) at different } \\
\text { DAT }\end{array}$} & \multicolumn{3}{|c|}{$\begin{array}{c}\text { Number of tillers }\left(\mathbf{m}^{-2}\right) \\
\text { at different DAT } \\
\end{array}$} & \multicolumn{3}{|c|}{$\begin{array}{c}\text { Dry matter }\left(\text { tha }^{-1}\right) \text { at } \\
\text { different DAT }\end{array}$} \\
\hline & 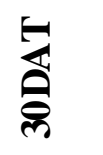 & 拞 & $\frac{5}{8}$ & 吝 & 商 & 㝵 & 胥 & 商 & $\frac{5}{8}$ & 量 \\
\hline Kalijira & 48.73 & 64.27 & 82.55 & 117.90 & 174 & 332 & 400 & 0.44 & 1.67 & 3.20 \\
\hline Katanibhog & 44.54 & 60.54 & 75.86 & 10833 & 172 & 314 & 373 & 0.37 & 1.56 & 2.98 \\
\hline Chinigura & 47.70 & 57.83 & 73.04 & 106.62 & 203 & 366 & 431 & 0.52 & 2.03 & 3.49 \\
\hline Badshabhog & 41.89 & 67.92 & 81.18 & 122.95 & 157 & 300 & 347 & 0.39 & 1.60 & 2.91 \\
\hline Mean & 45.72 & 62.64 & 78.16 & 113.95 & 177 & 328 & 388 & 0.43 & 1.72 & 3.15 \\
\hline Significance & 0.01 & 0.01 & 0.01 & 0.01 & 0.01 & 0.01 & 0.01 & 0.01 & 0.01 & 0.01 \\
\hline $\mathrm{CV}(\%)$ & 5 & 4.8 & 3.6 & 2.1 & 9.5 & 6.9 & 8.0 & 7.4 & 7.6 & 6.4 \\
\hline
\end{tabular}

*Figures in a column followed by different letters differ significantly, whereas, with common letter(s) do not differ significantly at $1 \%$ levels of significance.

Dry matter production of early-planted crop was lower and it increased with the advancement of transplanting dates (Table 1). The maximum dry matter was recorded in the late planted crop (25 January). The high tiller productive variety Chinigura produced the highest amount of dry matter and was then followed by Kalijira. On the contrary, the least amount of dry matter was observed in Kataribhog and Badshabhog irrespective of growth stages.

\section{Yield components}

Rice transplanted on 10 December produced the highest number of panicles and grains panicle $^{-1}$ which gradually decreased in late planted crops. In late planted ones, 10 January crop showed lower number of panicles and grains panicle ${ }^{-1}$ (Table 3$)$. These findings are in conformity with the results obtained by BRRI (2003). The Chinigura produced significantly the highest number of panicles but it was statistically identical with Kalijira, while, Kataribhog exhibited lower number of panicles but number of grains panicle ${ }^{-1}$ was found more in Badshabhog. The lowest number of grains panicle ${ }^{-1}$ was found in Kataribhog irrespective of planting date (Table 3). These results are in agreement with the results obtained by BRRI (2003) where Chinigura produced higher number panicles in the Boro season. The significant interaction effect of planting dates and the varieties showed that panicle production in Chinigura was higher over the rest of the varieties irrespective of planting date. The sterility percentage was significantly increased with the delayed planting date where the highest sterility percentage was found in the late planted crop (10 January crop) shown in Table 3. The highest spikelet sterility (48\%) was found in Chinigura while, 
the lowest $(43 \%)$ in Kalijira. The 1000-grain weight did not vary significantly due to transplanting dates. However, it varied significantly due to the varieties. The heaviest grain was found in Kataribhog while, the light grain was observed in Badshabhog (Table 3). Yoshida (1981) stated that the 1000-grain weight is stable varietals character, which remained unaffected due to the manipulation of management practices (BRRI, 2003).

\section{Grain Yield}

Early planted (10 December) crop gave significantly higher grain yield (3.13-3.53 $\mathrm{tha}^{-1}$ ) than the late-planted ones. The grain yield of rice gradually decreased with the delayed planting dates (Fig. 1).

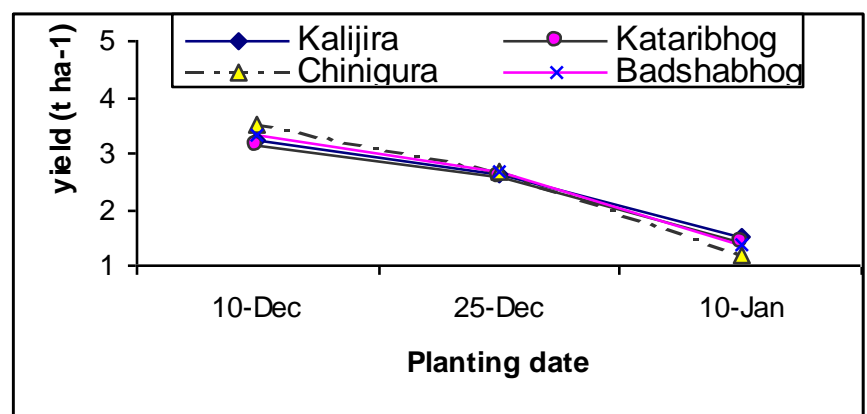

Fig. 1: Grain yield of traditional aromatic rice as affected by planting date, Boro seasons

Transplanting after 25 December resulted in sharp decrease of the grain yield. Probably, the lower number panicles and higher percentage of spkikelet sterility decreased the grain yield of late planting crop (Table 3). Further delaying in transplanting after 10 January, the yield was very low. This fact well agrees with the results of BRRI (2003). The highest yield of early-planted crop was due to timely plantation that produced higher number of panicles $\mathrm{m}^{-2}$ and grains panicle ${ }^{-1}$, less sterility and flowered when ample solar energy was available and the temperature was relatively warmer in March during grain filling stage (BRRI, 2003; Salam et al., 2004). These findings are in conformity with the results obtained by Salam et al. (2004) who found better yield in boro season (BRRI, 2003).

The grain yield of Chinigura and Kalijira was almost identical. Lower grain yield was found in Kataribhog which may be attributed to the lower number of panicles and grain panicle ${ }^{-1}$. Similar findings were reported by BRRI (2003) while conducting experiments in boro season. Interaction effect of planting dates and the varieties on grain yield showed that the transplanting within December, the Chinigura, Kalijira, Badshabhog and Kataribhog and produced higher grain yields (Table 3 ). That is the grain yield of rice gradually decreases due to delay in planting. Late transplanted (10 January) Kalijira and Kataribhog showed higher yields than the other varieties which may be attributed to the production of decreased the number of panicles per unit area, the panicle length and the number of grains panicle ${ }^{-1}$ and increased spikelet sterility (\%). Yield reduction of rice in late planted situation was mainly due to genotypic behavior (Magor, 1982; Bhuiyan and Salam, 2003). The results of this study indicated that due to delayed and shifting transplanting from 10 December to 25 December, the yield reduction was higher in Chinigura (49 $\mathrm{kg} \mathrm{ha}^{-1}$ day $\left.^{-1}\right)$ followed by Badshabhog (37 $\mathrm{kg} \mathrm{ha}^{-1}$ day $^{-1}$ ) and Kalijira $\left(33 \mathrm{~kg} \mathrm{ha}^{-1}\right.$ day $\left.^{-1}\right)$. The drastic yield reduction was found in the crop when transplanting shifted from 25 December to 10 January. It was estimated that the yield reduction of Chinigura was about $109 \mathrm{~kg} \mathrm{ha}^{-1}$ day $^{-1}$, Badshabhog $93 \mathrm{~kg} \mathrm{ha}^{-1} \mathrm{day}^{-1}$, Kataribhog $80 \mathrm{~kg} \mathrm{ha}^{-1} \mathrm{day}^{-1}$ and Kalijira $81 \mathrm{~kg} \mathrm{ha}^{-1} \mathrm{day}^{-1}$ in late planting situations. 
Grain yield reduction in late planting situation indicated that none of the test variety gave satisfactory number of panicles and grains panicle ${ }^{-1}$ after 10 January. Although, some panicles of Kalijira emerged but most of them had sterile spikelets. Thus, it is suggested that photosensitive varieties should not be allowed to transplant after 25 December during boro season. The results confirm the findings of Salam et al., (1992) who found insignificant differences of grain yield between photosensitive and photo-insensitive varieties in early boro season. Zaman (1981) directed to transplant the photosensitive varieties within November for optimum photoperiodic induction to obtain satisfactory yields. However, the scenario of flowering behavior of photoperiod sensitive rice was different. Gomosta et al., (2001) reported that boro crop seeded in October and transplanted in November flowered in February when low night temperature caused spikelet abortion and increased spikelet sterility up to 64-84 percent and reduced grain yield drastically. Thus, during genotype selection emphasis should be given on the cold tolerance, photoperiod sensitivity and on the capacity to capture more solar radiation for the development of large panicle for higher grain yield in the boro season. However, the yield potentiality of the crop depends on the type of genotype and the environmental condition especially the air temperature and solar radiation of a particular area (Singh et al., 1997).

Table 3: Interaction effect of planting date and varieties on grain yield and yield component of traditional fine aromatic rice varieties in Boro season (Average of two years)

\begin{tabular}{|c|c|c|c|c|c|c|c|c|}
\hline \multirow{2}{*}{\multicolumn{2}{|c|}{$\begin{array}{l}\text { Treatments interaction } \\
\text { Planting dateXVarieties }\end{array}$}} & \multirow{3}{*}{$\begin{array}{l}\begin{array}{l}\text { Panicle } \\
\text { number } \\
\left(\mathrm{m}^{-2}\right)\end{array} \\
296 \mathrm{ab}\end{array}$} & \multirow{3}{*}{$\begin{array}{c}\begin{array}{l}\text { Grains } \\
\text { panick }^{-1}\end{array} \\
112 \mathrm{a}\end{array}$} & \multirow{3}{*}{$\begin{array}{l}\text { Sterility } \\
(\%) \\
23\end{array}$} & \multirow{3}{*}{$\begin{array}{l}\text { 1000-grain } \\
\text { wt. (g) } \\
11.01\end{array}$} & \multirow{3}{*}{$\begin{array}{l}\begin{array}{l}\text { Grain } \\
\text { yield } \\
\left(\text { tha }^{-1}\right)\end{array} \\
3.22 \mathrm{ab}\end{array}$} & \multirow{3}{*}{$\begin{array}{l}\begin{array}{l}\text { Straw } \\
\text { yield } \\
\left(\mathrm{tha}^{-1}\right)\end{array} \\
4.05 \mathrm{a}\end{array}$} & \multirow{3}{*}{$\begin{array}{l}\begin{array}{c}\text { Growth } \\
\text { duration } \\
\text { (days) }\end{array} \\
164 a\end{array}$} \\
\hline & & & & & & & & \\
\hline \multirow{4}{*}{ 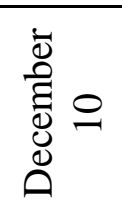 } & Kalijira & & & & & & & \\
\hline & Kataribhog & $271 b c$ & $77 b$ & 26 & 15.93 & $3.13 \mathrm{ab}$ & $3.77 \mathrm{ab}$ & $160 \mathrm{~b}$ \\
\hline & Chinigura & $331 \mathrm{a}$ & $90 \mathrm{ab}$ & 26 & 12.31 & $3.53 \mathrm{a}$ & $4.26 a$ & $160 \mathrm{~b}$ \\
\hline & Badshabhog & $274 b c$ & $125 \mathrm{a}$ & 21 & 10.35 & $3.32 \mathrm{a}$ & 3.74ab & $156 \mathrm{bc}$ \\
\hline \multirow{4}{*}{ 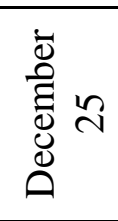 } & Kalijira & $284 b$ & $98 \mathrm{ab}$ & 30 & 10.99 & $2.72 b$ & $3.91 \mathrm{ab}$ & $153 \mathrm{bc}$ \\
\hline & Kataribhog & $259 \mathrm{bc}$ & $69 \mathrm{bc}$ & 33 & 15.85 & $2.68 \mathrm{~b}$ & $3.59 \mathrm{~b}$ & $149 \mathrm{bc}$ \\
\hline & Chinigura & $300 \mathrm{a}$ & $83 \mathrm{ab}$ & 30 & 12.25 & $2.79 b$ & $3.98 \mathrm{a}$ & $151 \mathrm{bc}$ \\
\hline & Badshabhog & $263 b c$ & $115 \mathrm{a}$ & 27 & 10.21 & $2.77 \mathrm{~b}$ & $3.46 \mathrm{bc}$ & $147 \mathrm{c}$ \\
\hline \multirow{4}{*}{$\begin{array}{l}\text { 怘 } \\
\text { 志 }\end{array}$} & Kalijira & $205 c$ & $74 b$ & 43 & 10.81 & $1.51 \mathrm{c}$ & $3.61 \mathrm{bc}$ & $149 \mathrm{bc}$ \\
\hline & Kataribhog & $192 \mathrm{c}$ & $56 c$ & 44 & 15.65 & $1.45 \mathrm{c}$ & $3.48 b c$ & $149 \mathrm{bc}$ \\
\hline & Chinigura & $205 c$ & $54 c$ & 48 & 11.82 & $1.16 \mathrm{~d}$ & $3.80 \mathrm{ab}$ & $150 \mathrm{bc}$ \\
\hline & Badshabhog & $206 c$ & $72 b$ & 45 & 10.21 & $1.38 \mathrm{~cd}$ & $3.26 c$ & $145 c$ \\
\hline$\stackrel{600}{\Omega s}$ & - & 0.05 & 0.01 & 0.01 & 0.01 & 0.01 & 0.01 & 0.01 \\
\hline 己 & - & 7.0 & 8.0 & 7.4 & 4.5 & 6.3 & 5.9 & 4.1 \\
\hline
\end{tabular}

*Figures in a column followed by different letters differ significantly but with common letter(s) do not differ significantly at $1 \%$ and $5 \%$ levels of significance.

\section{Straw yield}

The straw yield of rice varied significantly due to transplanting dates. The straw yield of early-planted crop increased over the late-planted ones (Table 3). The straw yield decreased 
with the advancement of the planting dates and less amount of straw was found in late planted on 10 January crop. Interaction effect of planting dates and the varieties on straw yield showed that the high tiller productive Chinigura exhibited the high amount of straw yield while, low tiller productive variety Kataribhog and Badshabhog sho wed low amount of straw yield irrespective of planting dates.

\section{Flowe ring behaviour and growth duration}

The early-planted (10 December) crop started flowering on 4 March and continued up to 16 March. The rice crop planted on 25 December started flowering from 9 March and ended on 22 March (Table 4). With the advancement of transplanting time (10 January) the flowering started from 24 March through 2 April. The Badshabhog flowered 1-7 days earlier than the other varieties while, Badshabhog. The flowering time of Kalijira delayed by 1-7 days compared Chinigura irrespective of planting dates. Perhaps the variations of flowering might be due to variations in photoperiod sensitivity. Photoperiod sensitive varieties are supposed to be cultivated during transplant Aman season having fixed flowering periodicity, but when cultivated in Boro season they showed variations in flowering times which might be due to variations of photoperiod sensitivity. Similar findings was reported by Salam et al., (1992) where photoperiod sensitive varieties had fixed flowering time, but when these were cultivated in Boro season they showed variations in flowering times. Probably, due to flowering variation a significant variation of growth duration was observed among the varieties.

Table 4: Effect of planting date on flowe ring behaviour of fine aromatic rice varieties in boro season

\begin{tabular}{|l|l|l|l|l|l|l|}
\hline Varieties & \multicolumn{2}{|c|}{10 December planting } & \multicolumn{2}{|c|}{25 December planting } & \multicolumn{2}{|c|}{ 10 January planting } \\
\cline { 2 - 7 } & $\begin{array}{l}\text { Flowering } \\
2 \%\end{array}$ & $\begin{array}{l}\text { Flowering } \\
75 \%\end{array}$ & $\begin{array}{l}\text { Flowering } \\
2 \%\end{array}$ & $\begin{array}{l}\text { Flowering } \\
75 \%\end{array}$ & $\begin{array}{l}\text { Flowering } \\
2 \%\end{array}$ & $\begin{array}{l}\text { Flowering } \\
75 \%\end{array}$ \\
\hline Kalijira & 10 March & 16 March & 16 March & 22 March & 28 March & 2 April \\
\hline Kataribhog & 5 March & 11 March & 10 March & 15 March & 26 March & 1 April \\
\hline Chinigura & 7 March & 12 March & 12 March & 17 March & 27 March & 2 April \\
\hline Badshabhog & 4 March & 10 March & 9 March & 15 March & 24 March & 29 March \\
\hline
\end{tabular}

The growth duration of fine rice variety varied due to the variation of transplanting dates. The growth duration gradually decreased with the advancement of planting dates. Probably, due to low temperature spelled at the early stage the crop establishment as well as tillering delayed, resulting in longer vegetative growth duration and delayed heading thereby prolonging the growth duration. These findings are in conformity with the results obtained by BRRI (1999).

The interaction effect of planting dates and varieties showed significant influence on growth duration. The Badshabhog and Kataribhog matured earlier while, Kalijira took long duration for its maturity irrespective of transplanting dates. The cold temperature prevailed (10.6-14.3 C) at the early crop growth stage (in January) and probably this was main factor for longer growth duration with the early transplanted crop than the late seeded ones. Similar findings 
also were reported by BRRI (2001). Thus, it may be concluded that it is important to cultivate high yield potential photoperiod sensitive traditional aromatic fine rice varieties having cold tolerance at the early growth stage which may be provided through transplanting them in early December to increase production in Boro season.

\section{REFERENCES}

Bhuiyan, N. I. and M. A. Salam. 2003. Research and Development of Boro Rice in Bangladesh. A Plant Breeding Prospective. Boro Rice. Indian Agril. Res. Inst., India. pp. 43-49.

Bhuiyan, N.I., D.N.R. Paul and M.A. Jabber. 2004. Feeding the Extra Millions by 2025: Challenges for Rice Research and Extension in Bangladesh. In: Proc. Workshop on Modern Rice Cultivation in Bangladesh, 29-31 January, 2002. Bangladesh Rice Res. Inst. Gazipur. pp. 1-3.

Biswas, S.K., B. Banu, K.A. Kabir, F. Begum and N.H. Choudhury. 1992. Physicochemical properties of modern and local rice varieties of Bangladesh. Bangladesh Rice J. 3(1\&2): 128-131.

BRRI (Bangladesh Rice Research Institute). 1996. Annual Report for 1993. Bangladesh Rice Res. Inst. Gazipur. Pub. no. 115. pp. 46-123.

BRRI (Bangladesh Rice Research Institute). 1999. Annual Report for January 1998-June 1999, Bangladesh Rice Res. Inst., Gazipur, Pub. no.135. pp.9-35, 243.

BRRI (Bangladesh Rice Research Institute). 2001. Cold Injury Problem in Boro Rice. In: Proc. of the Workshop on Modern Rice Cultivation in Bangladesh. 14-16 February, 1999. Bangladesh Rice Res. Inst. Gazipur, Pub. no. 132. pp. 37-66.

BRRI (Bangladesh Rice Research Institute). 2003. Annual Internal Review, held on 19-23 October, Agron. Divn. Bangladesh Rice Res. Inst. Gazipur, pp. 5-7.

BRRI (Bangladesh Rice Research Institute). 2004. Adunick Dhanar Chash (Bengla), Bangladesh Rice Res. Inst. Gazipur, Pub. no. 5. pp.12-35.

Gomosta, A.R., H.A. Quayyum and A.A. Mahbub. 2001. Tillering duration and yielding ability of rice varieties in the winter rice season in Bangladesh. Rice Research for Food Security and Poverty Alleviation. Editors, Peng S and Hardy B. Intl. Rice Res. Inst. Los Bonos, Philippines, pp. 87-94.

IRRI (International Rice Research Institute). 1992. User's Mannual. Version 92-1. Intl. Rice Res. Inst., Los Banos. Philippines. pp. 53-79.

Islam, M.R., M.S. Rahman, M.H. Rahman, M.A. Awal and M.G. Hossain. 1999. Effect of date of planting on rice yield and yield attributes of two advance mutants of rice in Aman season. Bangladesh J. Nucl. Agric. 15:34-40. 
Karim, Z. 1997. Accelerating Agricultural Growth In Bangladesh. Seminar on Agricultural Research and Development in Bangladesh. Intl. Conf. Center. Prim Minister`s Office. Dhaka, 24-25 February, Bangladesh Agrl. Res. Coun. pp. 4-20.

Magor, N. P. 1982. A Cropping Pattern Model for Rainfed Lowland Rice in the Bangladesh. M.S. Thesis. Univ. Sydney, Australia. pp. 1-13.

Pathak, A.K., P.K. Pathak and K.K. Sharma. 2003. Recent Development in Boro Rice Improvement and Production for Raising Rice Yield in Assam. Boro Rice. Edi. Singh RK, Hossain M and.Thakur R Intl. Rice Res. Inst. India Office, Pusa Campus, New Delhi-110012, India, pp.73-80.

Roy, B.C. 1999. Nitrogen Fertilizer Management and its Effect on Growth and Yield of Rice Varieties in Bangladesh. Ph.D. Thesis, Verlag Grauer. Stuttgart. Univ. Hohenheim (380). Germany. pp. 1-17.

Salam, M.A., M.A. Kabir and N.M. Miah. 1992. Adaptability of photoperiod-sensitive modern rice varieties in the Boro season. Bangladesh Rice J. 3(1\&2): 144-147.

Salam, M.A., F. Ali, M.P. Anwar and M.S.U. Bhuiya. 2004. Effect of nitrogen level and date of transplanting on the yield and yield attributes of transplanted Aman rice under SRI method. J. Bangladesh Agril. Univ. 2(1): 31-36.

Singh, K.M., S.K. Pal, U.N. Verma, R. Thakur and M.K. Singh. 1997. Effect of time and methods of planting on performance of rice (Oryza sativa) cultivars under medium land of Bihar Plateau. Indian J. Agron. 42(3): 443-445.

Yoshida, S. 1981. Fundamentals of Rice Crop Science. Intl. Rice Res. Inst. Los Banos, Philippines. pp. 41-248.

Yoshihashi, T. 2005. Does Drought Condition Induce the Aroma Quality of Aromatic Rice. Japan Intl. Res. Center for Agril. Sci. (JIRC AS). Food Sci. Divn. News Letter for Intl. Collaboration. no. 45. Japan. p. 4.

Zaman, S.M.H. 1981. Simple Techniques of Rice Production. In Proc. Workshop on Modern Rice Cultivation in Bangladesh. February, 1980. Bangladesh Rice Res. Inst. Gazipur, pp.31-39 